\title{
Symptomatic and functional effects of N-Acetylcysteine in primary acquired nasolacrimal stenosis
}

\author{
Mehmet Rasih Abidinoglu' ${ }^{1}$, Burak Turgut ${ }^{2 *}$ and Tamer Demir ${ }^{2}$ \\ ${ }^{1}$ Etimed Hospital, Eye Diseases Clinic, Ankara \\ ${ }^{2}$ Onsekiz Mart Üniversity, Faculty of Medicine, Department of Ophthalmology, Çanakkale
}

\begin{abstract}
Purpose: To research the effects of N-Acetylcysteine on lacrimation complaint and the opening of the nasolacrimal duct in the cases with primary acquired nasolacrimal duct stenosis (PANS).

Materials and methods: A total of 56 patients aged between 16-69 were diagnosed with PANS was started the treatment with NAS four drops per a day. The presence of epiphora and feeling of watering in the nasal passage with nasolacrimal canal (NLC) lavage before drug use was compared after one month of treatment.

Results: Twenty-seven (48.21\%) of 56 patients had a feeling of nasal watering with lavage. In 32 (57.14\%) of the patients, it was found that subjectively watering and epiphora were decreased. Recurrence was observed in 30 of 56 patients (53.57\%) at the end of the treatment of 3 months.

Conclusion: In the patients with PANS due to mucus plug formation, NAS may provide symptomatic and functional success. It may be considered in the treatment of patients who are not suitable for surgery or who do not want surgery. As a next step, the lavage of NLC with NAS can provide more effective and long-term results.
\end{abstract}

\section{Introduction}

Primary acquired naso-lacrimal duct stenosis (PANS) is a common cause of epiphora and is thought to be associated with chronic inflammation due to an unknown cause and to be a result of the development of fibrosis causing stenosis. Ocular and periocular diseases such as conjunctival and nasal infections, trauma, sinusitis, toxicity (exposure to trichloramine in pool water) and chronic anti glaucomatous drop treatment, mechanical causes, atopic diseases, and allergic rhino-conjunctivitis may cause secondary nasolacrimal stenosis with inflammation and fibrosis [1-8].

The treatment of PANS is conventional external and endonasal dacryocystorhinostomy and modified surgical procedures with nonendoscopic or mechanical or laser, osteotomy opening of various sizes with mucosal flap, mitomycin-C applied or stent placement. Success rates range from $50 \%$ to $100 \%$, and recurrence may occur in some cases [9-22].

$\mathrm{N}$-Acetylcysteine (NAS) is an acetyl derivative of L-cysteine, a natural amino acid, and has mucolytic, antioxidant and corneal collagenase enzyme inhibitor effects. It regulates the production and secretion of mucus by its action on the mucus elasticity/viscosity. Due to its mucolytic and anticholinergic effects, it has been used successfully in dry eye, meibomian gland dysfunction, filamentary keratitis, corneal ulcer, corneal mucous plaque, and alkali corneal burns. In cases of excessive mucus secretion and cases due to filaments, the mucolytic effect occurs when the free sulphydryl (-SH) group in the NAS breaks the disulfide (-S-S-) bridges in mucoprotein molecules of the mucus [22-44].

In the literature, we could not detect the publication regarding the use of NAS in the treatment of PANS. For this reason, we aimed to evaluate the effects of NAS on irrigation complaints and duct patency in PANS cases which we think that the occlusion is caused by a mucous plug.

\section{Material and methods}

56 patients were included in the study, ranging in age from 16-69 and diagnosed as PANS. NAS 4x1 drops started to be applied to eyes with PANS. Nasal and throat examinations were performed before the lavage procedure in order to determine the possible pathologies in the nasal cavity and the lower meatus. The patients who had no nasal pathology and were included in the study. The nasolacrimal duct (NLC) lavage was performed from the lower punctum. Epiphora and NLC lavage and the presence of nasal tearing sensation were compared before the beginning of drug use and after one month of treatment. The study was conducted in accordance with the Helsinki Criteria. Written consent was obtained for the publication of the results of the study and the study.

\section{Results}

The mean age of patients was 44,7 years (ranging from 16 to 69 years). Twenty-seven (48.21\%) of 56 patients had nasal watering sensation with lavage. In $32(57.14 \%)$ of the patients, it was found that subjectively watering and complain epiphora were decreased.

${ }^{\star}$ Correspondence to: Burak Turgut, Onsekiz Mart University, Faculty of Medicine, Department of Ophthalmology, 17270 Çanakkale, Turkey, E-mail: drburakturgut@yahoo.com

Key words: epiphora, acquired, nasolacrimal duct, stenosis, N-Acetylcysteine, drop Received: November 19, 2018; Accepted: November 30, 2018; Published: December 03, 2018 
Recurrence was observed in 30 of 56 patients $(53.57 \%)$ at the end of the treatment of 3 months.

\section{Discussion}

NAS is the acetyl derivative of L-cysteine, a natural amino acid, and it has mucolytic, antioxidant and anticholinergic effects. NAS regulates the production and secretion of mucus by its action on the mucus elasticity/viscosity. The mucolytic effect on the cases of excessive mucus secretion and filaments is caused by the free sulphydryl (-SH) group in the NAS, which breaks down the disulfide (-S-S-) bridges in the mucoprotein molecules of the mucus [22-44]. In the literature, pressure NAS application in the treatment of NLK obstruction in rabbits has been reported [22-45]. This is aimed at removing obstruction due to thickened mucus. We have achieved partial success with NAS drop in this case series with no pathology causing secondary stenosis. In our study, the application was not made with pressure lavage but as a drop. This may be a reason for the partial success in our study. We think that the NAS may possibly be due to its anti-inflammatory and mucolytic properties. However, detailed and histopathological studies are needed for the effect of fibrosis.

\section{Conclusion}

Although the relapse rate is high, or the treatment is temporary, the NAS may be able to achieve symptomatic and functional success in PANS cases, probably due to a mucus plug formation. In cases where the stenosis is thought to be due to the mucous plug, it may be considered in the treatment if it is not suitable for the operation or does not want the operation.

\section{References}

1. Tanenbaum M, McCord CD (2001) Lacrimal drainage system. In: Tasman W (ed) Duane's clinical ophthalmology. Vol. 4. Revised ed. Lippincott, Williams \& Wilkins: Philadelphia: $1-34$.

2. Hirschbein MJ, Stasior GO (2001) Lacrimal system. In: Chen WP (ed) Oculoplastic surgery, the essentials, 1st ed, Thieme; New York: 263-288.

3. Linberg JV, McCormick SA (1986) Primary acquired nasolacrimal duct obstruction. A clinicopathologic report and biopsy technique. Ophthalmology 93: 1055-1063. [Crossref]

4. Kashkouli MB, Sadeghipour A, Kaghazkanani R, Bayat A, Pakdel F, et al. (2010) Pathogenesis of primary acquired nasolacrimal duct obstruction. Orbit 29: 11-15. [Crossref]

5. Ohtomo K,Ueta T, Toyama T, Nagahara M (2013) Predisposing factors for primary acquired nasolacrimal duct obstruction. Graefes Arch Clin Exp Ophthalmol 251: 18351839. [Crossref]

6. Seider N, Miller B, Beiran I (2008) Topical glaucoma therapy as a risk factor for nasolacrimal duct obstruction. Am J Ophthalmol 145: 120-123. [Crossref]

7. Jacobs JH, Spaan S, van Rooy GB, Meliefste C, Zaat VA, et al. (2007) Exposure to trichloramine and respiratory symptoms in indoor swimming pool workers. Eur Respir J 29: 690-698. [Crossref]

8. Schaefer DP (2015) Acquired Etiologies of Lacrimal System Obstructions. In: Cohen A., Mercandetti M., Brazzo B. (eds) The Lacrimal System. Springer: Cham: 43-68.

9. Patel BC (2009) Management of acquired nasolacrimal duct obstruction: external and endonasal dacryocystorhinostomy. Is there a third way? Br J Ophthalmol 93: 14161419. [Crossref]

10. Dolman PJ (2003) Comparison of external dacryocystorhinostomy with nonlaser endonasal dacryocystorhinostomy. Ophthalmology 110: 78-84. [Crossref]

11. Tarbet KJ, Custer PL (1995) External dacryocystorhinostomy. Surgical success, patient satisfaction, and economic cost. Ophthalmology 102: 1065-1070. [Crossref]

12. Hanna IT, Powrie S, Rose GE (1998) Open lacrimal surgery: a comparison of admission outcome and complications after planned day case or inpatient management. Br J Ophthalmol 82: 392-396. [Crossref]
13. Hartikainen J, Antila J, Varpula M, Puukka P, Seppä H, et al (1998) Prospective randomized comparison of endonasal endoscopic dacryocystorhinostomy and external dacryocystorhinostomy. Laryngoscope 108: 1861-1866. [Crossref]

14. Ben Simon GJ, Joseph J, Lee S, Schwarcz RM, McCann JD, et al (2005) External versus endoscopic dacryocystorhinostomy for acquired nasolacrimal duct obstruction in a tertiary referral center. Ophthalmology 112: 1463-1468. [Crossref]

15. Caldwell GW (1983) Two new operations for obstruction of the nasal duct with preservation of the canaliculi, and an incidental description of a new lacrymal probe. NY Med J 57: 581.

16. West JM (1910) A Window Resection of the Nasal Duct in Cases of Stenosis. Trans Am Ophthalmol Soc 12: 654-658. [Crossref]

17. Benger R, Forer M (1993) Endonasal dacryocystorhinostomy--primary and secondary. Aust N Z J Ophthalmol 21: 157-159. [Crossref]

18. Woog JJ, Kennedy RH, Custer PL, Kaltreider SA, Meyer DR, et al (2001) Endonasal dacryocystorhinostomy: a report by the American Academy of ophthalmology. Ophthalmology 108: 2369-2377. [Crossref]

19. Christenbury JD (1992) Translacrimal laser dacryocystorhinostomy. Arch Ophthalmol 110: 170-171. [Crossref]

20. Rosen N, Barak A, Rosner M (1997) Transcanalicular laser-assisted dacryocystorhinostomy. Ophthalmic Surg Lasers 28: 723-726.

21. Mickelson SA, Kim DK, Stein IM (1997) Endoscopic laser-assisted dacryocystorhinostomy. Am J Otolaryngol 18: 107-111. [Crossref]

22. Brown SI, Tragakis MP, Pearce DB (1972) Treatment of the alkali-burned cornea. Am J Ophthalmol 74: 316-320. [Crossref]

23. Li X, Stark GR (2002) NFkappaB-dependent signaling pathways. Exp Hematol 30 285-296. [Crossref]

24. Kawakami S, Kageyama Y, Fujii Y, Kihara K, Oshima H (2001) Inhibitory effect of $\mathrm{N}$-acetylcysteine on invasion and MMP-9 production of T24 human bladder cancer cells. Anticancer Res 21: 213-219. [Crossref]

25. Lappas M, Permezel M, Rice GE (2003) N-Acetyl-cysteine inhibits phospholipid metabolism, proinflammatory cytokine release, protease activity, and nuclear factorkappaB deoxyribonucleic acid-binding activity in human fetal membranes in vitro. $J$ Clin Endocrinol Metab 88: 1723-1729. [Crossref]

26. Beloosesky R, Gayle DA, Amidi F, Nunez SE, Babu J, et al (2006) N-acetylcysteine suppresses amniotic fluid and placenta inflammatory cytokine responses to lipopolysaccharide in rats. Am J Obstet Gynecol 194: 268-273. [Crossref]

27. Haut J, Labrune P, Ullern M, Chermet M (1977) [New trial treatment of dry eye with acetylcysteine ophthalmic solution]. Bull Soc Ophtalmol Fr 77: 165-167. [Crossref]

28. Petroutsos G, Guimaraes R, Giraud JP, Renard G, Pouliquen Y (1982) Effect of acetylcysteine (Mucomyst) on epithelial wound healing. Ophthalmic Res 14: 241-248. [Crossref]

29. Sugar A, Waltman SR (1973) Corneal toxicity of collagenase inhibitors. Invest Ophthalmol 12: 779-782. [Crossref]

30. Thermes F, Molon-Noblot S, Grove J (1991) Effects of acetylcysteine on rabbit conjunctival and corneal surfaces. A scanning electron microscopy study. Invest Ophthalmol Vis Sci 32: 2958-2963. [Crossref]

31. Aldavood SJ, Behyar R, Sarchahi AA, Rad MA, Noroozian I, et al. (2003) Effect of acetylcysteine on experimental corneal wounds in dogs. Ophthalmic Res 35: 319-323. [Crossref]

32. Sarchahi AA, Maimandi A, Tafti AK, Amani M (2008) Effects of acetylcysteine and dexamethasone on experimental corneal wounds in rabbits. Ophthalmic Res 40: 41-48. [Crossref]

33. Akyol-Salman I, Azizi S, Mumcu U, Baykal O (2010) Efficacy of topical $\mathrm{N}$-acetylcysteine in the treatment of meibomian gland dysfunction. J Ocul Pharmacol Ther 26: 329-333. [Crossref]

34. Pelle E, Ingrassia M, Mammone T, Marenus K, Maes D (1998) Protection against cigarette smoke-induced damage to intact transformed rabbit corneal cells by $\mathrm{N}$-acetylLcysteine. Cell Biol. Toxicol 14: 253-259. [Crossref]

35. Gicquel JJ, Vabres P, Dighiero P (2005) [Use of topical cutaneous N-acetylcysteine in the treatment of major bilateral ectropion in an infant with lamellar ichthyosis]. $J \mathrm{Fr}$ Ophtalmol 28: 412-415. [Crossref] 
36. Redondo P, Bauzá A (1999) Topical N-acetylcysteine for lamellar ichthyosis. Lancet 354: 1880. [Crossref]

37. Sekharam M, Trotti A, Cunnick JM, Wu J (1998) Suppression of fibroblast cell cycle progression in G1 phase by N-acetylcysteine. Toxicol Appl Pharmacol 149: 210-216. [Crossref]

38. Absolon MJ, Brown CA (1968) Acetylcysteine in kerato-conjunctivitis sicca. $\mathrm{Br} J$ Ophthalmol 52: 310-316. [Crossref]

39. Slansky HH, Berman MB, Dohlman CH, Rose J (1970) Cysteine and acetylcysteine in the prevention of corneal ulcerations. Ann Ophthalmol 2: 488-493.

40. Brown SI, Weller CA (1970) Collagenase inhibitors in prevention of ulcers of alkaliburned cornea. Arch Ophthalmol 83: 352-353. [Crossref]
41. Brown SI, Tragakis MP, Pearce DB (1972) Treatment of the alkali-burned cornea. Am J Ophthalmol 74: 316-320. [Crossref]

42. Fraunfelder FT, Wright P, Tripathi RC (1977) Corneal mucus plaques. Am J Ophthalmol 83: 191-197. [Crossref]

43. Pokupec R, Petricek I, SikiÄ J, BradiÄ M, Popovï̈,Suï̈ S, et al. (2005) [Comparison of local acetylcysteine and artificial tears in the management of dry eye syndrome] Acta Med Croatica 59: 337-340. [Crossref]

44. Yalçin E, Altin F, Cinhüseyinoglue F, Arslan MO (2002) N-acetylcysteine in chronic blepharitis. Cornea 21: 164-168. [Crossref]

45. Enache AE, Ionascu I (2012) Management of dacryocystitis in a rabbit. Scientific Works. C Series. Veterinary Medicine. LVIII 4: 120-127.

Copyright: (O2018 Abidinoglu MR. This is an open-access article distributed under the terms of the Creative Commons Attribution License, which permits unrestricted use, distribution, and reproduction in any medium, provided the original author and source are credited. 